\section{Hypoacousis prevalence in Kaiowá and Guarani indigenous children}

\section{Prevalência de hipoacusia em crianças indígenas Kaiowá e Guarani}

\begin{abstract}
Objectives: to determine hypoacousis prevalence in Kaiowá and Guarani indigenous children.

Methods: a cross-sectional study was performed using a sample of 126 indigenous children from zero to 59 months old from the Caarapó Indian Reserve, Mato Grosse do Sul, Brazil. Hearing ability screening was performed by measuring transient evoked otoacoustic emissions. Children with hearing impairment were retested. Confirmed cases following retest were referred to imitanciometry testing.

Results: during hearing ability screening, 25 (23.6\%) children showed hearing impairment. Seventeen children had normal outcomes during retest and six of them confirmed hearing impairment and were referred to imitanciometry testing. Hypoacousis prevalence identified by the study reached $5.6 \%, 3(2.8 \%)$ and $3(2.8 \%)$ suggestive of conductive and sensorineural types, respectively. The last ones were referred to complementary otorhinolaryngologic assessment for diagnosis confirmation. Hearing impairment cases determined by this study were not statistically significant when related to gender and age.

Conclusions: problems concerning the prevalence of hearing impairment determined in the focused population suggest the need for hearing health programs to be developed with other child health programs.
\end{abstract}

Key words Epidemiology, Hearing loss, Indian, South American, Otoacustic emissions spontaneous

\author{
Renata Palópoli Pícoli 1 \\ Luana Carandina 2 \\ Dulce Lopes Barbosa Ribas 3
}

\begin{abstract}
1 Faculdade de Saúde Pública. Universidade de São Paulo. Av. Dr. Arnaldo 715. Pinheiros. São Paulo, SP, Brasil. CEP: 01.246-904 E-mail: rpicoli@usp.br

2 Departamento de Saúde Pública. Faculdade de Medicina de Botucatu. Universidade Estadual Paulista. Botucatu, SP, Brasil. 3 Departamento de Tecnologia de Alimentos e Saúde Pública. Universidade Federal de Mato Grosso do Sul. Campo Grande, MS,
\end{abstract} Brasil.

\section{Resumo}

Objetivos: identificar a prevalência de hipoacusia em crianças indígenas Kaiowá e Guarani.

Métodos: estudo transversal, com uma amostra de 126 crianças indígenas de zero a 59 meses da Terra Indígena de Caarapó, em Mato Grosso do Sul, Brasil. As crianças foram submetidas ao exame das emissões otoacústicas evocadas transitórias, que serviu como triagem auditiva. $O$ reteste foi realizado nas crianças que apresentaram resultado alterado na triagem auditiva. Os casos que, no reteste, permaneceram alterados foram encaminhados para o exame da imitanciometria.

Resultados: na triagem auditiva, foram identificadas $25(23,6 \%)$ crianças com resultado alterado; dessas, 17 apresentaram resultado normal no reteste e 6 permaneceram com resultado alterado, sendo encaminhadas para imitanciometria. A prevalência de hipoacusia identificada ao final do estudo foi de $5,6 \%$, sendo $3(2,8 \%)$ do tipo condutiva e $3(2,8 \%)$ do tipo neurossensorial. Estas últimas foram encaminhadas à avaliação otorrinolaringológica complementar para confirmação diagnóstica. As alterações auditivas identificadas neste estudo não apresentaram diferenças significantes quanto ao sexo e grupo etário.

Conclusões: a prevalência de alteração auditiva encontrada nesta população alerta para a necessidade de implantação de programas de saúde auditiva e sua articulação com outras ações desenvolvidas na atenção à saúde infantil dos Kaiowá e Guarani.

Palavras-chave Epidemiologia, Perda auditiva, Índios Sul-Americanos, Emissões otoacústicas espontâneas 


\section{Introduction}

Many documents prove the deep social, political, economic and cultural transformation of indigenous people following interethnical contact.1,2 Studies focusing Brazilian indigenous people health conditions have been gradually valued in the last decades to assess the impact of these changes in their epidemiological profile.

Contemporary Guaranis are conventionally divided into three subgroups: Ñhandéva/Chiripá, the M'byá and the Kaiowá, two of these sub-groups are located in the state of Mato Grosso do Sul: the Kaiowá and the Ñhandéva, the last ones are the only ones who name themselves Guarani. They inhabit in the 28 indigenous lands located in the Southern region of the State with an estimated population of 37.317 .3

In the last decades, the Guaranis and Kaiowás already bad life conditions, has drastically worsened. Progressive territorial losses, social organization changes, growing relationship with the surrounding economy and environmental contamination have taken their toll on these indigenous populations child health. 1,4

In the scope of the discussions related to indigenous health, several papers have focused on the epidemiological profile of high morbidity and mortality diseases, as for example, child malnutrion and respiratory conditions. 5,6 Health problems that are less common, such as hearing impairment are still few. In the Brazilian literature, only two documents investigating indigenous people's hearing were found. Picoli 7 has determined a $16.2 \%$ prevalence of hearing impairment among the Kaiowá and the Guarani school aged children. Another study performed with the adult Guarani population, in the State of São Paulo, determined that indigenous more isolated from urban life noises had lower hearing intensity levels when compared to non-indigenous individuals. 8

International literature refer to hearing impairment as one of the main heath problems among North American indigenous populations with prevalence of the middle ear influenced by very poor housing conditions, overpopulation, unfavorable physical environmental and malnutrition. 9,10

Hearing is one of the senses conveying important information concerning human development, specially linguistic and psychosocial aspects and should mature concurrently with other afferent, efferent or motor pathways and global development. 10

Hearing impairment is defined as a deviation or injury in the hearing structure or function extrapolating the limits or normalcy. ${ }^{11}$

Otoacoustic emissions have been amply used in hearing screening programs, specifically external cilliary cells and notwithstanding the fact of not quantifying hearing loss, they do detect when it occurs, for they are present in all ears with normal hearing, and are not seen when hearing levels are above 20-30 dBHL (deciBel hearing level). 12,13

Otoacoustic emissions can be classified as: spontaneous when captured without sound stimulus; transitory evoked otoacoustic emissions (TEOE) require sound stimulus, clicks or tone burst; and distortion product - using two pure sounds generally with different frequencies stimulating the cochlea and producing different frequency responses to initial signals, distortion products. 13,14

To interpret otoacoustic emissions results not only the external cilliary cells integrity must be considered, but the middle and external ears as well, for any alteration is sufficient to eliminate or reduce otoacoustic emission's amplitude, interfering with cochlea transmission and capturing of the small amplitude sounds generated. 15

Another form of assessing the hearing system, specially the middle year physiology is acoustic imitanciometry, an objective, fast and easy method, registering information on the ossicular-tympanum system motility and hearing pathways integrity. 16

The objective of this paper was to determine hypoacousis in the Kaiowá and Guarani of the Caarapó indigenous reserve.

\section{Methods}

A cross sectional study was performed with an initial sample of 126 children from zero to 59 months old of the Kaiowá and Guarani indigenous populations, from November 2003 to February 2004. Sample size was obtained with a confidence interval of $95 \%$ based on the total of under five years old children from the Indigenous Reservation of Caarapó enrroled in the Food and Nutritional Surveillance Program in the Indigenous Special Sanitation District in the Mato Grosso do Sul State, Brazil.

Audiologic evaluation was performed in three phases. The first one related to hearing screening with the application of transitory evoked otoacoustic emissions in the home environment of each child to identify children with a condition suggesting peripheral hearing alteration. Children with normal results, as previously described by Scamatti et al.,17 were excluded from the study. The second phase was 
named the retest phase and used the same procedure of the previous phase. Only the children with altered results as determined by the first transitory evoked otoacoustic emissions test participated. Acoustic imitanciometry test was performed in the third phase in children whose results remained altered during retest to detect conductive hearing alterations preventing the interpretation of the TEOE test. Retest and imitanciometry were performed in the Basic Health Unit of the Caarapó Indigenous Reserve. Prior to TEOE and imitanciometry testing, the children were submitted to a visual inspection of the external acoustic meatus.

The device used to register TEOE was Otodynamics model Echocheck Screening, and the criterion employed for normalcy was the presence of a green light indicating the presence of TEOE.

The following variables were considered: child age including months according to categories: 0-5, 6-11, 12-23, 24-59; sex and ear side.

For imitanciometry the device used was a clinical imitanciometer of the Madsen brand, model Zodiac 901. Tympanograms were classified according to the criteria described by Jerger, 18 with the Type A curve found in individuals with a normal middle ear, Type $\mathrm{B}$ curve in individuals with liquid in the middle ear and Type $\mathrm{C}$ in individuals with tubarian dysfunction.

Patients with altered TEOE and acoustic imitan- ciometry tests' results were referred to medical follow up in the Basic Health Unit of the Indigenous Reserve of Caarapó or by an otorhynolaringologist medical specialist in the city of Dourados.

The statistical pack used for data analysis was the version 6.12 of SAS. Data were expressed in absolute numbers and percentages. A significance level of $p<0,05$ was established. Variables were compared by the Chi-square test and Fisher's exact test.

The project was approved by the Research Ethical Committee of the Federal University of Mato Grosso do Sul and the National Commission for Ethical Research. Authorization of the Caarapó Indigenous Reserve leaders was obtained by written consent.

\section{Results}

One hundred and six children of the 126 ones in the sample were examined with the loss of 20 (15.9\%) of the children. Of these, 2 (1.6\%) did not participate of the study because they were not at home during the three visits to contact them and another 12 $(9.5 \%)$ cried without control making test performance impossible and $6(4.8 \%)$ had obstruction of the external acoustic meatus.

Of the 106 children evaluated, $62(58.5 \%)$ were

Table 1

Answer distribution for transitory evoked otoacoustic emissions according to gender, age group and ear side. Indigenous Reserve of Caarapó, Mato Grosso do Sul, 2004.

\begin{tabular}{|c|c|c|c|c|c|c|}
\hline \multirow{2}{*}{ Variables/categories } & \multicolumn{2}{|c|}{ Normal } & \multicolumn{2}{|c|}{ Impaired } & \multicolumn{2}{|c|}{ Total } \\
\hline & $\mathrm{n}$ & $\%$ & $\mathrm{n}$ & $\%$ & $\mathrm{n}$ & $\%$ \\
\hline Male & 32 & 72,7 & 12 & 27,3 & 44 & 100,0 \\
\hline \multicolumn{7}{|l|}{ Age group (months) } \\
\hline 0 a 5 & 6 & 66,7 & 3 & 33,3 & 9 & 100,0 \\
\hline 6 a 11 & 6 & 54,5 & 5 & 45,5 & 11 & 100,0 \\
\hline \multicolumn{7}{|l|}{ Ear side } \\
\hline Right ear & 96 & 90,5 & 10 & 9,5 & 106 & 100,0 \\
\hline Left ear & 91 & 85,9 & 15 & 14,1 & 106 & 100,0 \\
\hline
\end{tabular}


Audiologic phases of indigenous children according to answer type and behavior. Indigenous Reserve of Caarapó, Mato Grosso do Sul, 2004.

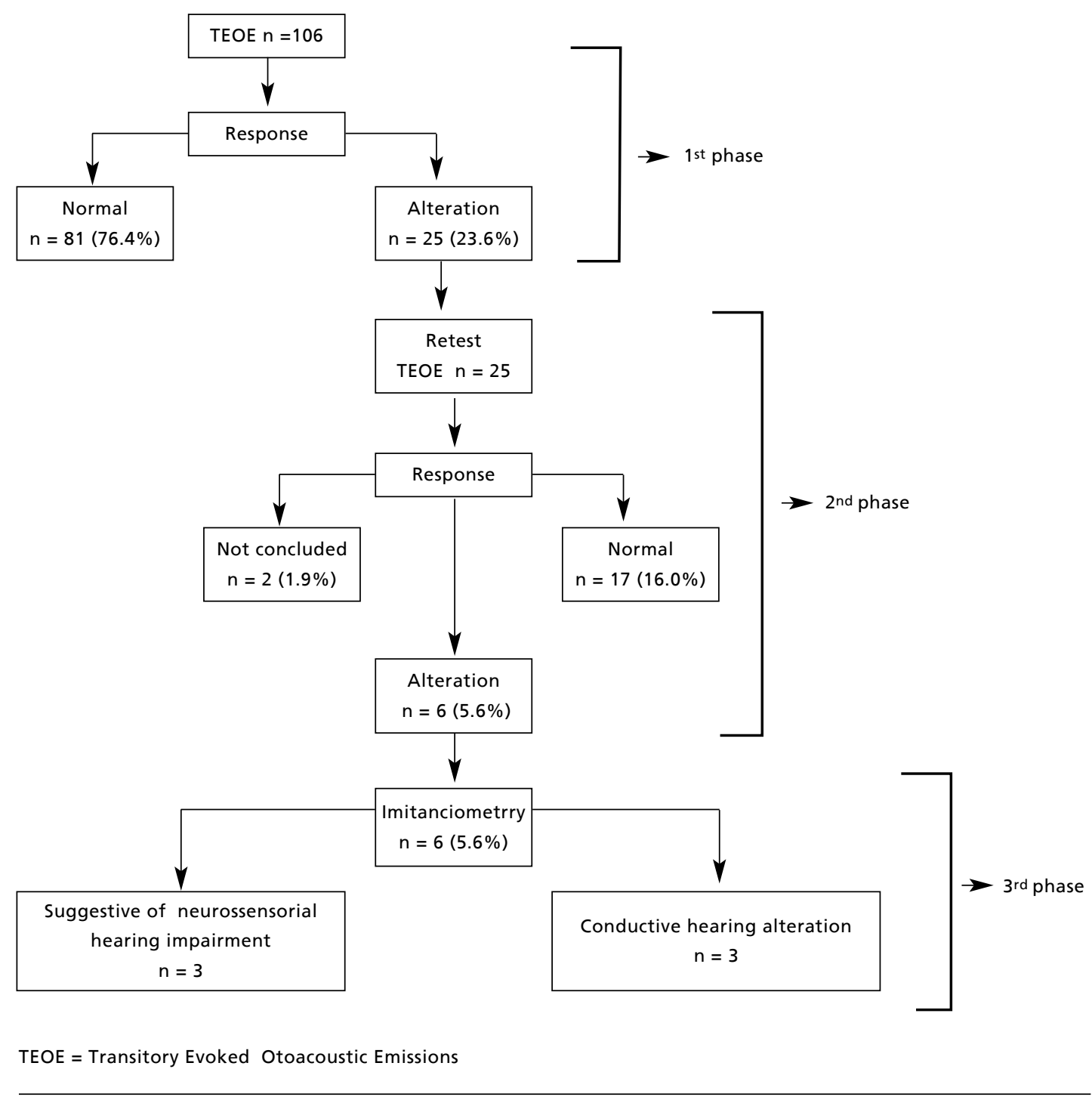

female and $44(41.5 \%)$ were males. As for the age group $9(8.5 \%)$ were aged between zero and five months, $11(10.4 \%)$ from 6 to 11 months, $30(28.3 \%)$ from 12 to 23 months and $56(52.8 \%)$ were between 24 and 59 months. During the hearing screening, 25 $(23.6 \%)$ of the children had altered results of the TEOE test. Of these, 12 were boys and 13 were girls with no statistically significant difference between the sexes $(p=0.3)$. A higher frequency was determined for children with altered results aged between 6 to $11(45.5 \%)$ months and between zero and 5
(33.3\%) months. Considering the proportion of children in each age group, there was no statistically significant difference determined $(p=0.149)$ (Table 1).

It was determined that no child had bilateral hearing impairment and approximately $23 \%$ had unilateral impairment. As for ear side 15 (14.1\%) children had left ear impairment and 10 (9.5\%) right ear impairment with no statistically significant difference (Table 1).

Retest determined that $17(68.0 \%)$ of the 25 chil- 
dren had normal results and that $6(24.0 \%)$ remained showing altered results and were referred to imitanciometry testing. In this phase there was a loss of 2 ( $8 \%)$ of the children who did not go to the Basic Health Unit facility.

During imitanciometry, three of the children showed a Type A bilateral typanometric curve, one of them a type $C$ curve in the left ear and Type $A$ curve in the right and two children had a type B unilateral tympanometric curve.

Hypoacousis prevalence identified at the end of the study was of $5.6 \%$ with $3(2.8 \%)$ of the conductive type and $3(2.8 \%)$ neurosensorial suggestive, the last were referred to otorhinolaryngologic complementary assessment for diagnostic confirmation (Figure 1).

\section{Discussion}

This study had constraints related to the number of children participating of the three phases, because of family migrations to other indigenous land and test rejection of some of the children in submitting to the TEOE test. The home environment where hearing screening was performed could have contributed to this rejection in addition to not offering adequate conditions caused by the presence of noise.

Nevertheless, this procedure was operation wise the more viable one because it consisted of fieldwork performed in an indigenous community with the requirement of mothers'acceptance and family trust. In addition, access to the Basic Health Center is difficult due to the spatial distribution of good part of the dwellings.

The choice of methods for the hearing test in this study was primarily based on the suspicion and identification of children with hearing impairment as determined by TEOE test and imitanciometry performed in the Basic Health Unit, with the purpose of confirming impairment cases and investigating conductive hearing alterations. The choice of the Basic Health Center for retesting and imitanciometry had the purpose of using the benefits of technical and logistical resources.

Different results obtained in the number of children with altered results at the time hearing screening and retest took place could be blamed on the noisy home environment interfering in the TEOE test in addition to the time difference between the two phases an average of 45 days. Such interval, due to operational issues could have contributed to find the children in different otologic conditions.
The hearing alterations found in this study did not determine significant differences related to sex and age group. Comparison difficulties of these results with the ones found in the literature involve the use of different methodologies and hearing assessment methods as well as populations of different age group and race.

Hypoacousis prevalence was higher than determined by Nelson e Berry ${ }^{19}$ who identified $2.3 \%$ of the conductive type hypoacusia and $0.4 \%$ of neurosensorial hypoacusia in the Navajo child population and lower when compared to the results obtained by Roberts 20 who identified $19 \%$ of preschool indigenous children with audiometry detected hearing impairment.

Hypoacousis prevalence determined among the Kaiowá and Guarani children was lower than the one noted by Vallejo et al.21 of $9.7 \%$ in non-indigenous children and similar to what was found by Dell'Aringá et al.22 In the attempt to approximate results of this study with others accomplished with non-indigenous children it is important to be aware of methodology interpretation issues specially concerning the fact that health conditions of nonindigenous children are different from the Kaiowá and Guarani children with very high morbidity and mortality rates caused by respiratory diseases, diarrheas and malnutrition which certainly impact conductive hearing.

Epidemiological studies have determined a higher prevalence of conductive hearing alterations among North American indigenous populations when compared to non-indigenous populations. 10,23 Moore 9 when investigating conductive hearing impairment risks among pre-school and school children of three ethnic groups in Canada, found that indigenous children have 2.5 more chances of having conductive hearing impairment than nonindigenous individuals.

Prevalence of hearing alterations determined by this study is an important health issue because of the possible impact on children's language and audition development and alerts to the need of implementing hearing health related to other child health programs for the Kaiowá and Guarani populations.

\section{Acknowledgements}

To the indigenous health agents for their care and commitment during fieldwork. To the Research Support Foundation of the State of São Paulo for their financial support (process 03/05283-9). 


\section{References}

1. Brand AJ. Desenvolvimento local em comunidades indígenas no Mato Grosso do Sul: a construção de alternativas. Rev Inter Desenvol Local. 2001; 2: 59-68.

2. Grunberg FP. Reflexões sobre a situação dos Guarani no Mato Grosso do Sul, Brasil. Brasília (DF): Equipe de Acompanhamento dos Guarani, Centro de Trabalho Indigenista; 2002.

3. FUNASA (Fundação Nacional de Saúde). Dados demográficos da população Kaiowá e Guarani de Mato Grosso do Sul. Disponível em URL: www.funasa.gov.br/renisi [2006 fev 16].

4. Pícoli RP. Saúde infantil: aspectos audiológicos e nutricionais da população infantil Kaiowá e Guarani, Área Indígena de Caarapó, Mato Grosso do Sul [dissertação mestrado]. Botucatu: Faculdade de Medicina da Universidade Estadual Paulista; 2005.

5. Ribas DLB, Philippi ST. Aspectos alimentares e nutricionais de mães e crianças indígenas Teréna, Mato Grosso do Sul. In: Coimbra Jr CEA, Santos RV, Escobar AL, organizadores. Epidemiologia e saúde dos povos indígenas no Brasil. Rio de Janeiro: Fiocruz, Abrasco; 2003. p. 73-88.

6. Pícoli RP, Carandina L, Ribas DB. Saúde materno-infantil e nutrição de crianças Kaiowá e Guarani, Área Indígena de Caarapó-MS. Cad Saúde Pública. 2006; 22: 223-7.

7. Pícoli RP. Prevalência de alterações auditivas em escolares indígenas Kaiowá/Guarani de Mato Grosso do Sul [especialização]. Campo Grande: Universidade Católica Dom Bosco; 2004.

8. Caso ACGN, Carvallo RMM. Estudo audiométrico em aldeias indígenas do Estado de São Paulo. Arq Otorrinolaringol. 2003; 7: 232-9.

9. Moore JA. Comparison of risk of conductive hearing loss among three ethnic groups of Arctic audiology patients. J Speech Lang Hear Res. 1999; 42: 1311-22.

10. Northern LJ, Downs MP. Audição em crianças. 3. ed. São Paulo: Manole; 1989.

11. Joint Committee on Infant Hearing. Year 2000 position satement: principles and guidelines for early hearing detection and intervention programs. Am J Audiol. 2000; 9: 929.

Received June 6, 2005

Final version in May 23, 2006

Approved May 29, 2006
12. Costa SMB, Costa Filho AO. Estudo das emissões otoacústicas evocadas em recém-nascidos pré-termo. Pró-Fono Rev Atual Cien. 1998; 1: 21-9.

13. Probst R, Harris F. Otoacoustic emissions. Adv Otorhinolaryngol. 1997; 53: 182-204.

14. Norton SJ, Stover LJ. Emissões otoacústicas: um novo instrumento clínico. In: Katz J. Tratado de audiologia clínica. São Paulo: Manole; 1999. Cap. 29, p. 444-58.

15. Lopes OF, Carlos R. Emissões otoacústicas na avaliação da audição em crianças. In: Shi T, editor. Otorrinolaringologia pediátrica. Rio de Janeiro: Revinter; 1998. p. 217-20.

16. Carvallo RMM. Medidas de imitância acústica em crianças de zero a oito anos de meses [tese doutorado]. São Paulo: Escola Paulista de Medicina; 1992.

17. Scamatti FC, Soares E, Chiriboga LM. Comparação das respostas em neonatos normais para emissões otoacústicas evocadas nos equipamentos: ILO 292 e ILO Ecocheck. Rev Bras Otorrinolaringol. 2003; 69: 549-51.

18. Jerger JF. Clinical experience with impedance audiometry. Arch Otolaryngol. 1970; 92: 311-24.

19. Nelson SM, Berry RL. Ear disease and hearing loss among Navajo children - a mass survey. Laryngoscope. 1984; 94 : 316-23.

20. Roberts ME. Comparative study of pure-tone, impedance, and otoscopic hearing screening methods. A survey of native Indian Children in British Columbia. Arch Otolaryngol. 1976; 102: 690-4.

21. Vallejo JC, Oliveira JAA, Silva MN, Gonçalves AS, Andrade MH. Análise das emissões otoacústicas em crianças com e sem risco auditivo. Rev Bras Otorrinolaringol. 1999; 65: 332-6.

22. Dell'Aringá AR, Dell'Aringá AHB, Juarez AJC, Melo C, Perches Filho RM. Emissões otoacústicas por produto de distorção em crianças de 2 a 7 anos. Rev Bras Otorrinolaringol. 2004; 3: 380-4.

23. Caldas N, Caldas Neto S. Otite média aguda. In: Costa SS, Cruz OL, Oliveira JAA, editores. Otorrinolaringologia: princípios e prática. Porto Alegre: Artes Médicas; 1994. p. 123-6. 